1 University of Debrecen, Centre of Agricultural Sciences, Department of Animal Breeding and Nutrition, Debrecen, Hungary

2 Research Institute of Animal Breeding and Nutrition, Herceghalom, Hungary

MARIANN ÁRNYASI ${ }^{1}$, ATTILA ZSOLNAI ${ }^{2}$, ISTVÁN KOMLÓSI ${ }^{1}$, LÁSZLÓ FÉSÜS ${ }^{2}$ and ANDRÁS JÁVOR ${ }^{1}$

\title{
Case study of a Hungarian breeding program using imported Booroola rams
}

\begin{abstract}
The first major gene for prolificacy identified in sheep was the Booroola $(\mathrm{FecB})$ gene. Since the recognition of its existence, the Booroola Merino has spread all over the world. In Hungary, a new breed - called Hungarian Prolific Merino - had been established based on the crossing of Hungarian Merino ewes and Booroola Merino rams, and was acknowledged in 1992. The only way to determine the FecB genotypes has been the measurement of the ovulation rate over a long period. In 2001, the Booroola mutation was identified. Mutation on the bone morphogenetic protein receptor - $1 \mathrm{~B}$ gene was found to be associated with the increased ovulation rate in the Booroola Merino ewes. 138 ewes and 46 rams in the Hungarian Prolific Merino population were tested for this mutation by PCR-RFLP and their FecB genotypes were determined. One copy of the $\mathrm{Fec}^{\mathrm{B}}$ allele increased $(\mathrm{P}<0,05)$ the ovulation rate by 0.89 ova and two copies increased by an average of 2.27 ova. Effectiveness of the FecB genotype estimation based on phenotype measurement was also compared to the results of direct DNA testing, and was found to have up to $80 \%$ accuracy.
\end{abstract}

Key Words: FecB gene, direct DNA test, Hungarian Prolific Merino

\section{Zusammenfassung}

Titel der Arbeit: Fallstudie über ein ungarisches Zuchtprogramm mit importierten Booroola Schafböcken Das erste Hauptgen für die Fruchtbarkeit, das bei Schafen gefunden werden konnte, war das Booroola (FecB) Gen. Nach der Anerkennung seines Bestehens hat sich die Booroola Merino Schafrasse auf der ganzen Welt verbreitet. In Ungarn wurde durch Einkreuzung von Booroola Merino Schafböcken in ungarische Merino Mutterschafe eine neue Rasse, das Ungarische Fruchtbare Merino, gezüchtet. Diese wurde 1992 als neue und eigenständige Rasse bestätigt. Die einzige Methode, die FecB Genotypen festzustellen, war bisher die Messung der Ovulationsrate über eine lange Periode. Im Jahr 2001 wurde die Booroola Mutation identifiziert. Die Mutation am Knochen Morphogenetische Protein Receptor - dem 1B Gen - schien mit der steigenden Ovulationsrate der Booroola Merino Mutterschafe verbunden zu sein. 138 Mutterschafe und 46 Böcke aus der Ungarischen Fruchtbaren Merino Population wurden für diese Mutation mit PCR-RFLP getestet und ihre FecB Genotypen festgestellt. Das $\mathrm{Fec}^{\mathrm{B}}$ Allel erhöht $(\mathrm{P}<0,05)$ die Ovulationsrate um 0,89 Ova und zwei Allele erhöhen die Rate im Durchschnitt um 2,27 Ova. Die Schätzung der Wirksamkeit des FecB Genotyps auf Grund der phänotypischen Messung wurde auch mit dem direkten DNS Test verglichen. Dabei konnten die Ergebnisse mit einer Genauigkeit von über $80 \%$ abgesichert werden.

Schlüsselwörter: FecB Gen, direkter DNS Test, Ungarische Fruchtbare Merino

\section{Introduction}

Profitability of sheep breeding is mainly determined by litter size. Selection for prolificacy based on phenotype has a low genetic gain (SAFARI and FOGARTY, 2003). (Another possibility is conducting selection using breeding values (BLUP)). Beyond this some investigations deal with the effect of the Booroola gene on the quality of the end products (KLEEMANN et al., 1988; SUESS et al., 2000). Based on the national data set of the Hungarian Merino sheep, an insignificant genetic trend was 
found in litter size (NAGY, 2000). Major genes for production traits provide opportunities for large and rapid increases in the efficiency of sheep production. The first major gene for prolificacy identified in sheep was the Booroola (FecB) gene in Australia, which has additive effects on ovulation rate and is dominant for litter size (DAVIS et al., 1982; PIPER and BINDON, 1982). After the recognition of the existence of the single gene, Booroola Merino has spread all over the world. In Europe, Hungary was the first country that imported Booroola Merino rams and ewes (VERESS, 1983). A new breed, called Hungarian Prolific Merino, was established based on the crossing of Booroola Merino rams and Hungarian Merino ewes, and was acknowledged in 1992. The aim of the breeders was to create and maintain a homozygous flock for the $\mathrm{FecB}$ locus and use it in cross breeding programmes (VERESS et al., 1987). To date, the carriers of the $\mathrm{Fec}^{\mathrm{B}}$ allele were identified on the basis of ovulation rate records in the case of ewes, and extensive progeny testing in the case of rams. This method is time and labour consuming, which hinders its practical application.

Until the Booroola gene itself is identified, genetic markers linked to the FecB locus might assist in the introgression of the $\mathrm{Fec}^{\mathrm{B}}$ allele into new breeds. The FecB locus has been assigned to sheep chromosome 6 (MONTGOMERY et al., 1993) and localised in a region of $10 \mathrm{cM}$ between two microsatellites BM1329 and OarAE101 (LORD et al., 1998). Suitability of these microsatellites as markers for the identification of the Fec ${ }^{B}$ carriers were investigated in different countries and found to represent efficient and robust genotyping system (LEYHE-HORN et al., 1998; GOOTWINE et al., 1998; WEIMANN et al., 2001). Based on these results, BM1329 and OarAE101 microsatellites were tested in the Hungarian Prolific Merino sheep. Unfortunately, these markers were not suitable for identifying the carriers of the $\mathrm{Fec}^{\mathrm{B}}$ allele (ÁRNYASI et al., 2003) because of the low level of heterozygosity and the relatively low population size.

In 2001, a point mutation at the position 830 of the bone morphogenetic protein receptor - 1B gene (GenBank accession number AF312016) was found to be associated with increased ovulation rate in Booroola Merino ewes by different research groups (WILSON et al., 2001; SOUZA et al., 2001; MULSANT et al., 2001). This nucleotide substitution results in a change from glutamine the wild type to an arginin in the Booroola animals, which leads to a partial inactivation of the BMPR-1B resulting in the 'precocious' development of a large number of small antrall follicules. The aim of this study was to demonstrate that the high ovulation rate in the Hungarian Prolific Merino is caused by the mutation in the BMPR-1B receptor gene and to compare the effectiveness of the genotyping method based on the ovulation rate to the results of the direct gene test.

\section{Materials and Methods}

The Hungarian Prolific Merino population, which is bred at the research farm of the University of Debrecen, Centre of Agricultural Sciences, was involved in the investigation.

\section{Estimation of FecB genotypes by indirect methods}

Before the identification of the FecB mutation, the FecB genotypes were estimated by counting corpora lutea during laparoscopic examination in the ewes. The ovulation 
rate (OR) data were collected from ewes at natural oestrus cycle in autumn as described by MAGYAR (1994). FecB genotypes of 90 ewes (group A) were estimated and later compared to the results of the direct gene test. The animals (Table 1 ) have been classified as homozygous non-carriers $\left(\mathrm{Fec}^{+} \mathrm{Fec}^{+}\right.$) with an OR of 2 or less, heterozygous carriers $\left(\mathrm{Fec}^{\mathrm{B}} \mathrm{Fec}^{+}\right.$) with average $\mathrm{OR}$ of 3 and homozygous carriers $\left(\mathrm{Fec}^{\mathrm{B}} \mathrm{Fec}^{\mathrm{B}}\right.$ ) with an average OR of 4 or more (VERESS et al., 1998).

In the case of rams, different sources of information were available to estimate the FecB genotypes. In 1986, 4 Booroola rams were imported from New Zealand. These animals (group B) were genotyped based on the OR of their mothers and estimated FecB genotypes of their fathers by the breeders in New Zealand.

Three Booroola Merino and 8 Hungarian Prolific Merino rams (group C) were classified based on the OR data of their daughters from 1988-1993. In this case, the ovulation rate of the daughters was measured after PMSG treatment at 6 months of age, as described by VERESS (1991).

From 1986-1996, FecB genotypes of a further 10 rams (5 Booroola and 5 Hungarian Prolific Merino) (group D) were estimated. Their genotypes were determined based on their pedigree and the OR data of their daughters. In this case, the OR was measured in normal oestrus cycle without PMSG treatment (MAGYAR et al., 1999). The FecB genotypes of 25 rams were estimated altogether.

The indirect methods used for estimation of FecB genotype is summarised in Table 1.

Table 1

Summary of the indirect methods used for the estimation of FecB genotype (Übersicht der indirekten Methoden zur Schätzung des FecB Genotypes)

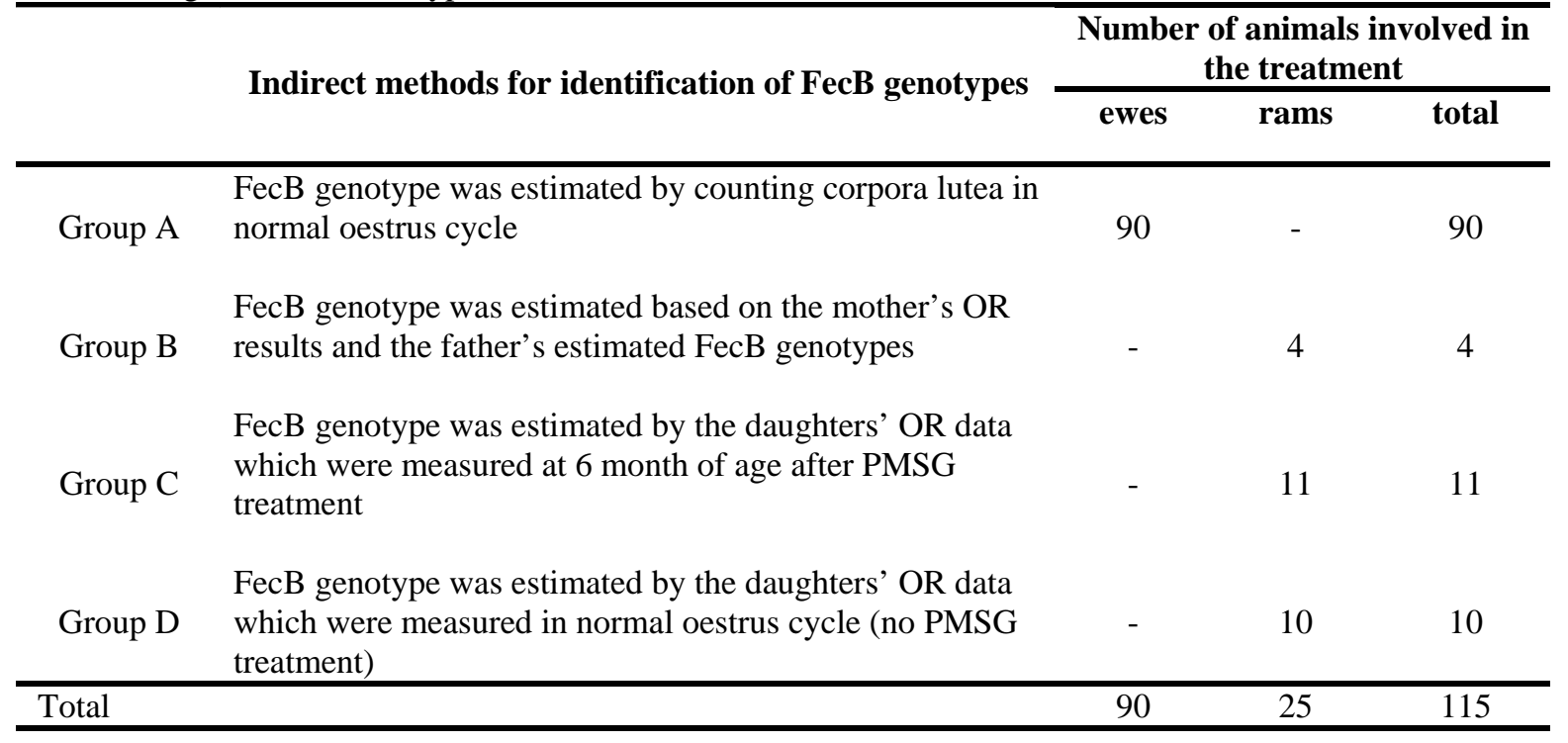

Determination of the FecB genotypes by using a direct gene test

By using the direct gene test, 139 ewes and 46 rams altogether were genotyped (involving the 90 ewes and 25 rams, which had estimated FecB genotypes and further 49 young ewes and 21 rams, which had no estimated FecB genotypes) for the Booroola mutation in 2003 (Table 2).

The PCR-RFLP technique using primers and restriction enzyme (AvaII) as described by WILSON et al. (2001) was used for the detection of the mutation in the bone morphogenetic receptor type $1 \mathrm{~B}$ (BMPR-1B) gene. DNA was isolated from blood and semen samples as reported by ZSOLNAI and FÉSÜS (1996). For PCR, 10 $\mu$ l reaction 
contained 20-100 $\mathrm{MM}$ genomic DNA, 10xPCR buffer, $1.5 \mathrm{mM} \mathrm{MCl}_{2}, 0.2 \mathrm{mM}$ of each primer and 0.25U Taq DNA polymerase (Promega). The PCR profile included an initial denaturation of $1 \mathrm{~min}$ at $94^{\circ} \mathrm{C}$ followed by 35 cycles of $15 \mathrm{sec}$ at $94^{\circ} \mathrm{C}, 30 \mathrm{sec}$ at $65^{\circ} \mathrm{C}$ and $30 \mathrm{sec}$ at $72^{\circ} \mathrm{C}$. The fragments were resolved on a $4 \%$ agarose gel and scored for the mutation.

\section{Statistical Analyses}

Least Square Means of the OR in the three groups of $\mathrm{FecB}$ genotype $\left(\mathrm{Fec}^{\mathrm{B}} \mathrm{Fec}^{\mathrm{B}}\right.$; $\mathrm{Fec}^{\mathrm{B}} \mathrm{Fec}^{+}$; $\mathrm{Fec}^{+} \mathrm{Fec}^{+}$) were calculated. Mixed Model Least-Squares and Maximum Likelihood Computer Programme PC-2 were used for the ANOVA (HARVEY, 1999). The FecB genotype determined by direct DNA test, the year and the age of ewes at the time of OR measurement were involved into the model as fix effects. The ovulation rate data (115 measurement altogether) of 64 pedigree ewes (Table 2) were involved in the analyses of variance because of the availability of the fix effects data.

The accuracy of the estimation of FecB genotypes was calculated by comparing the estimated genotypes to the genotypes determined by the direct gene test. The correspondence was expressed in percentage.

Table 2

Summary of the number of animals having $\mathrm{FecB}$ genotypes determined by different methods (Tierbestand mit dem FecB Genotyp, bestimmt mit verschiedenen Methoden)

\begin{tabular}{lccc}
\hline & \multicolumn{2}{c}{ Number of animals } \\
\cline { 2 - 4 } & ewes & rams & Total \\
\hline $\begin{array}{l}\text { Having FecB genotypes determined by both indirect } \\
\text { methods and direct gene test }\end{array}$ & $90 *$ & 25 & 115 \\
\hline $\begin{array}{l}\text { Having FecB genotypes determined by direct gene test } \\
\text { only }\end{array}$ & 49 & 21 & 70 \\
\hline Total & 139 & 46 & 185 \\
\hline OR data of 64 ewes out of the 90 were involved in the ANOVA & &
\end{tabular}

\section{Results}

\section{Ovulation rate distribution}

The arithmetical mean of the OR was 3.12. 8.70\% of the measured OR were $1,33.91 \%$ were 2 , and $57.39 \%$ were 3 or more indicating the presence of the FecB mutation in the population (Table 3 ).

\section{Table 3}

Distribution of the ovulation rate in the Hungarian Prolific Merino population $(n=115)$ (Verteilung der Ovulationsrate in der Ungarischen Fruchtbaren Merino Population)

\begin{tabular}{ccccccc}
\hline Number of Corpoa Lutea & $\mathbf{1}$ & $\mathbf{2}$ & $\mathbf{3}$ & $\mathbf{4}$ & $\mathbf{5}$ & $\mathbf{6}$ \\
\hline Distribution of the OR (\%) & 8.70 & 33.91 & 19.13 & 17.39 & 16.52 & 4.35 \\
\hline
\end{tabular}

Table 4

The least square means (LS-means) of the ovulation rate based on the FecB genotypes in the Hungarian Prolific Merino population (LSQ-Mittelwert (LS-Mean) der Ovulationsrate aufgrund der FecB Genotypen in der Ungarischen Fruchtbaren Merino Population)

\begin{tabular}{cccc}
\hline FecB genotypes & $\begin{array}{c}\text { Number of observation } \\
\mathbf{n}\end{array}$ & LS means \pm SD \\
\hline $\mathrm{Fec}^{+} \mathrm{Fec}^{+}$ & 11 & $1.70 \pm 0.44$ & $\mathrm{a}$ \\
$\mathrm{Fec}^{\mathrm{B}} \mathrm{Fec}^{+}$ & 51 & $2.59 \pm 0.29$ & $\mathrm{~b}$ \\
$\mathrm{Fec}^{\mathrm{B}} \mathrm{Fec}^{\mathrm{B}}$ & 53 & $3.97 \pm 0.30$ & $\mathrm{c}$ \\
\hline
\end{tabular}


The FecB genotype was found to have a significant effect on OR at a level of $\mathrm{P}<0.05$. Differences were significant between all the three genotypes at a level of $\mathrm{P}<0.05$ (Table 4). In the case of 64 Hungarian Prolific Merino ewes, the ovulation rate was increased by 0.89 by one copy of the $\mathrm{Fec}^{\mathrm{B}}$ allele. Homozygous carriers had an ovulation rate higher than the non-carriers by 2.27 .

\section{Effectiveness of the estimation of the FecB genotypes}

Effectiveness of the genotyping methods based on phenotype measurement was calculated comparing to the results of the direct DNA test (Table 5). In the case of ewes, estimated FecB genotypes were determined to $80 \%$ accurately and overestimated in $20 \%$. In the case of rams, big differences were found in genotypes determined by direct DNA test comparing to the results of estimation based on the progeny test or the parents' genotype. The FecB genotypes of 4 rams (group B) imported from New Zealand were estimated as $\left(\mathrm{Fec}^{\mathrm{B}} \mathrm{Fec}^{\mathrm{B}}\right)$ homozygous carriers by the Australian breeders. Applying the direct DNA test, one of the four rams was proved to be a homozygous carrier and three of them were genotyped as $\mathrm{Fec}^{\mathrm{B}} \mathrm{Fec}^{+}$.

\section{Table 5}

Accuracy of estimation of FecB genotypes based on phenotype measurement comparing to the results of direct gene test (Genauigkeit der Schätzung der FecB Genotypen aufgrund der phänotypischen Messungen im Vergleich mit dem direkten Gen Test)

\begin{tabular}{cccc}
\hline & $\begin{array}{c}\text { Properly assigned } \\
(\%)\end{array}$ & Over assigned (\%) & Under assigned (\%) \\
\hline Ewes & 79 & 20 & 1 \\
A & & & 0 \\
Rams & 25 & 75 & 10 \\
B & 45 & 45 & 0 \\
C & 80 & 2 & \\
D & & &
\end{tabular}

In the case of five rams out of the 11 rams of group $C$ the results of the direct gene test and the classified genotypes were in agreement. One heterozygous ram was misclassified to homozygous, and five $\mathrm{Fec}^{\mathrm{B}} \mathrm{Fec}^{+}$rams were classified as homozygous carriers. In this case, the estimation of the FecB genotypes was accurate in $45 \%$ (Table 5).

In the case of eight rams of group D, the estimated FecB genotypes corresponded to the results of the DNA test. The genotypes of two rams were wrongly assumed. The accuracy of the estimation of FecB genotype $(80 \%)$ was found to be similar to the results for ewes.

Table 6

Distribution of the breeding animals based on their FecB genotype in the Hungarian Prolific Merino population (Verteilung der Zuchttiere auf Grund ihrer FecB Genotypen in der Ungarischen Fruchtbaren Merino Population)

\begin{tabular}{cccc}
\hline FecB genotypes & $\mathbf{B B}$ & $\mathbf{B}$ & $\mathbf{+ +}$ \\
$\mathbf{\%}(\mathbf{n})$ & $\mathbf{\%}(\mathbf{n})$ & $\mathbf{\%}(\mathbf{n})$ \\
\hline Ewes & & & \\
Hungarian Prolific Merino & $37.41(52)$ & $43.88(61)$ & $18.71(26)$ \\
\hline Rams & & & \\
Booroola Merino & $33.33(5)$ & $53.33(8)$ & $13.33(2)$ \\
Hungarian Prolific Merino & $48.39(15)$ & $45.16(14)$ & $6.45(2)$ \\
\hline
\end{tabular}


Distribution of the FecB genotypes in 2003

The distribution of the present female Hungarian Prolific Merino population based on their FecB genotype determined by direct gene test is the following: $37.41 \%$ are $\mathrm{Fec}^{\mathrm{B}} \mathrm{Fec}^{\mathrm{B}}$ homozygous, $43.88 \%$ are $\mathrm{Fec}^{\mathrm{B}} \mathrm{Fec}^{+}$heterozygous and $18.71 \%$ are $\mathrm{Fec}^{+} \mathrm{Fec}^{+}$ homozygous. Regarding to the whole flock, the portion of animals carrying the $\mathrm{Fec}^{\mathrm{B}}$ allele in a homozygous form is $38.9 \%$, in heterozygous form is $44.8 \%$ (Table 6 ).

\section{Discussion}

Mutation in the BMPR-1B receptor gene is proved to result in the high ovulation rate in the Hungarian Prolific Merino population on the basis of the results of the one-way ANOVA between ovulation rate and FecB genotypes. Although, it was published that the Booroola mutation has an additive effect on ovulation rate by PIPER et al. (1985), different results were obtained in our experiment. The ovulation rate of homozygous carriers had more than twice as much as the non-carriers. This phenomenon could be explained by the allele-allele interaction between the wild type $\left(\mathrm{Fec}^{+}\right)$and the $\mathrm{Fec}^{\mathrm{B}}$ allele. Similar case was observed in the crosses of Inverdale and Booroola Merino by Davis et al. (1999). When the 2 genes, the FecI and FecB, were in combination the OR was higher than the sum of the effects of each gene alone.

Distribution of the three FecB genotypes in the female and the male populations reflects that the aim of the breeders has not yet been fulfilled, since less than half of the whole population is homozygous $\mathrm{Fec}^{\mathrm{B}} \mathrm{Fec}^{\mathrm{B}}$. In this study great differences were found in the results of determination of FecB genotype by direct DNA test and estimation of the genotype based on ovulation rate in the female population. FecB genotype was overestimated by $20 \%$ by breeders. This explains, partly, the high frequency of the $\mathrm{Fec}^{\mathrm{B}} \mathrm{Fec}^{+}$heterozygous and $\mathrm{Fec}^{+} \mathrm{Fec}^{+}$non-carriers in the Hungarian Prolific Merino population. Moreover, FecB genotypes of the rams were also estimated improperly based on their progeny test. The accuracy of the estimation of FecB genotype was different depending on the PMSG treatment in the progeny test. Classification was found to be more accurate if it was based on the daughters' OR results which were measured in normal oestrus cycle, comparing to the methods wherein PMSG treatment was taken. Although several research groups used previously the PMSG treatment in the progeny tests to estimate the FecB genotype (CLEVERDON and HART, 1981; DAVIS and KELLY, 1983; OLDHAM et al., 1984; DAVIS and JOHNSTONE, 1985), this methods was proved to be not reliable in our experiment. Rams with genotype of $\mathrm{Fec}^{+} \mathrm{Fec}^{+}$or $\mathrm{Fec}^{\mathrm{B}} \mathrm{Fec}^{+}$were used for a long time because of the missed classification. This also gives a good explanation for the high frequency of the non-carriers, and the heterozygous $\left(\mathrm{Fec}^{\mathrm{B}} \mathrm{Fec}^{+}\right)$animals in the present population. No other publications were found to report data similar to those presented here.

In conclusion, results support that the high rate of ovulation is caused by the mutation in the BMPR-1B receptor gene in the Hungarian Prolific Merino. Efficiency of the breeding programme to increase the frequency of the $\mathrm{Fec}^{\mathrm{B}}$ allele in this population was hindered by the previously applied improper genotype classification.

Application of the direct DNA test will accelerate the spread of the $\mathrm{Fec}^{\mathrm{B}}$ allele in the flock. At present an experiment is under way for exploiting the connection between endocrinologycal processes (e.g. IGF, leptin level) and seasonality and litter size, respectively. 


\section{Acknowledgement}

The authors wish to thank the Ministry of Agriculture and Rural Development for the financial support (FVM-36013/03; FVM FKFP 0440/99), Gizella Szabó for the excellent technical assistance and the animal keeper from the Research Breeding Farm of the University of Debrecen, Centre of Agricultural Sciences.

\section{References}

ÁRNYASI, M.; ZSOLNAI, A.; FÉSÜS, L.; JÁVOR, A.: Importance of discovery of $\mathrm{FecB}$ gene in the breeding of Hungarian Prolific Merino. Buletinul USAMV-CN 59 (2003), 62-65

CLEVERDON, J. M.; HART, D. S.:

Oestrus and ovarian activity of Booroola Merino crossbred ewe hoggets. Proceeding N. Z. Soc. Anim. Prod. 41 (1981), 189-192

DAVIS, G.H.; DODDS, K.G.; BRUCE, G.D.:

Combined effect of the Inverdale and Booroola prolificacy genes on ovulation rate in sheep. Proc. of the $13^{\text {th }}$ Conf. Assoc. for the Advancement of Animal Breeding and Genetics (1999), 74-77

DAVIS, G. H.; JOHNSTONE, P. D.:

Ovulation response to pregnant mares serum gonadotrophin in prepubertal lambs of different Booroola genotypes. Anim. Repr. Sci. 9 (1985), 145-151

DAVIS, G. H.; KELLY, R. W.:

Segregation of a major gene influencing ovulation rate in progeny of Booroola sheep in commercial and research flock. Proceeding N. Z. Society Animal Production 43 (1983), 192-197

DAVIS, G.H.; MONTGOMERY, G.W.; ALLISON, A.J.; KELLY, R.W.; BRAY, A.R.:

Segregation of a major gene influencing fecundity in progeny of Booroola sheep New Zeeland Journal of Agricultural Research 25 (1982), 525-529

GOOTWINE, E.; YOSSEFI, S.; ZENOU, A.; BOR, A.:

Marker assisted selection for FecB carriers in Booroola Awassi crosses. Proc. 6th. World Congr. Genet. Appl. Lives. Prod., Armidale, Australia, 11-16, January. 24 (1998), 161-164

HARVEY, L.R.: Mixed Model Least-Squares and Maximum Likelihood Computer Programme PC-2. Manual (1999)

KLEEMANN, D. O.; PONZONI, R.W.; SATFFORD, J.E.; CUTTON, I. N.; GRIMSON, R.J.:

Carcass composition of the South Australian merino and its crosses with Booroola and Trangie. Australian J. of Exp. Agric. 28 (1988), 167-172

LEYHE-HORN, B.; KOCH, D.; GAULY, M.; ANASTASSIADIS, C.; ERHARDT, G.:

Suitability of microsatellites BM1329 and OarAE101 as markers for introgression of FecB locus into different sheep breeds. $49^{\text {th }}$ EAAP, Warsaw, Poland, 24-27 August. (1998)

LORD, E.A.; DAVIS, G.H.; DODDS, K.G.; HENRY, H.M.; LUMSDEN, J.M.; MONTGOMERY, G.W.: Identification of Booroola Carriers using microsatellite markers. 6th World Congr. on Genet. Appl. Lives. Prod., Armidale, New South Wales, Australia, 11-16 January (1998)

MAGYAR, K.:

Application of laparoscope methods in sheep breeding (Laparoszkópos módszerek alkalmazása a juhtenyésztésben). $\mathrm{PhD}$ thesis, Debrecen (1994)

MAGYAR, K.; VERESS, L.; TASI, ZS.; PÉCSI, T.; BABIK, S.; HORVÁTH, I.:

Zootechnical and genetic aspects of a Prolific merino program. Acta Veterinaria Hungarica. 47 (1999) $1,17-31$

MONTGOMERY, G.W.; CRAWFORD, A.M.; PENTY, J.M.; DODDS, K.G.; EDE, A.J.; HENRY, H.M.; PIERSON, C.A.; LORD, E.A.; GALLOWAY, S.M.; SCHMACK, A.E.; SISE, J.A.; SWARBRICK, P.A.; HANRAHAM, V.; BUCHANAN, F.C.; HILL, D.F.:

The ovine Booroola fecundity gene (FecB) is linked to markers from a region of human chromosome 4q. Nature Genetics. 4 (1993), 410-414

MULSANT, P.; LECERF, F.; FABRE, S.; SCHILBER, L.; MONGET, P.; LANNELUC, I.; PISSELET, C.; RIQUET, J.; MONNIAUX, D.; CALLEBAUT, I.; CRIBIU, E.; THIMONIER, J.; TEYSSIER, J.; BODIN, L.; COGNIE, Y.; CHITOUR, N.; ELSEN, J.M.:

Mutation in bone morphogenetic protein receptor-IB is associated with increase ovulation rate in NAGY, I.: Booroola Merino ewes. Proc. Natl. Acad. Sci. USA. 98 (2001) 9, 5104-5109

Quantitative genetic studies on the Hungarian Merino sheep population. Ph.D. thesis. Debrecen. (2000)

OLDHAM, C.M.; GRAY, S. J.; POINDRON, P.; BINDON, B. M.: 
Progeny testing for F gene using prepubertal ewe lambs. In: LINDSAY, D. R. and PEARCE, D. T. (eds) Reproduction in Sheep, Cambridge Univ. Press. (1984), 260-264

PIPER, L.R.; BINDON, B.M.:

The Booroola Merino and the performance of medium non-Peppin crosses at Armidale. in the Booroola Merino, Eds. L.R. PIPER, B.M. BINDON, R.D. NETHERY. Melbourne. Ed. CHIRO (1982), 9-20

PIPER, L.R.; BINDON, B.M.; DAVIS, G.H.:

The single gene inheritance of the high litter size of Booroola Merino, In: R.B. LAND, D.W. ROBINSON (eds.), Genetics of Reproduction in Sheep, London:Buterworth (1985), 115-125

SAFARI, A.; FOGARTY, N. M.:

Genetic Parameters for Sheep Production Traits: Estimates from the Literature. Technical Bulletin. NSW Agriculture. Orange. Australia 49 (2003)

SOUZA, C.H.J.; MACDOUGALL, C.; CAMPBELL, B.K.; MCNEILLY, A.S.; BAIRD, D.T.:

The Booroola $(\mathrm{FecB})$ phenotype is associated with a mutation in the bone morphogenetic receptor type 1 B (BMPR1B) gene. Journal of Endocrinology. 169 (2001), R1-R6

SUESS, R.; HEYLEN, K.; LENGERKEN, G. v.:

Einfluss von Booroola-Merinos auf den Fettgehalt und -qualität der Schlachtkörper bei Kreuzung mit Merinofleischschafen. Arch Tierz., Dummerstorf 43 (2000) 1, 45-56

VERESS, L.:

Data for the breeding programme of the Booroola Merino (Adatok a booroola merinó tenyésztési

VERESS, L.: programjához). Hungarian Journal of Animal Production. 32 (1983) 4, 329-334

Genetic and keeping technology questions involved in the development of sheep breeding (A juhtenyésztés fejlesztésének genetikai és tartástechnológiai kérdései) D.Sc. Dissertation, Hungarian Academy of Sciences, Budapest (1991)

VERESS, L.; MAGYAR, K.; KOMLÓSI, I.; JÁVOR, A.:

A sheep breeding program and the its results till now (Egy juhtenyésztési program és eddigi eredményei) Debrecen Review (Debreceni Szemle) 4 (1998), 565-581

VERESS, L.; VÉGH, J.; HORVÁTH, VNÉ.:

Breeding possibilities of the Booroola Merino in Hungary (A booroola merinó tenyésztési lehetőségei Magyarországon). Hungarian Journalof Animal Production 36 (1987) 1, 53-61

WEIMANN, C.; LEYHE-HORN, B.; GAULY, M.; ERHARDT, G.:

Suitability of microsatellites BM1329 and OarAE101 as markers for the introgression of the FecB locus into different sheep breeds. Arch. Tierz., Dummerstorf 44 (2001) 4, 435-440

WILSON, T.; WU, X.Y.; JUENGEL, J.L.; ROSS, I.K.; LUMSDEN, J.M.; LORD, E.A.; DODDS, K.G.;

WALLING, G.A.; MCEWAN, J.C.; O’CPNELL, A.R.; MCNEILLY, K.P.; MONTGOMERY, G.M.:

Highly Prolific Booroola Sheep Have a Mutation in the Intracellular Kinase Domain of Bone Morphogenetic Protein IB Receptor (ALK-6) that in Both Oocyte and Granulose Cells. Biology of Reproduction. 64 (2001), 1225-1235

ZSOLNAI, A.; FÉSÜS, L.:

Simultaneous analysis of bovine kappa-casein and BLAD alleles by multiplex PCR followed by parallel digestion with two restriction enzymes. Animal Genetics 3 (1996), 207-209

Received: 2004-03-01

Accepted: 2004-06-22

Corresponding author

DR. MARIANN ÁRNYASI PHD, research fellow

University of Debrecen

Centre of Agricultural Sciences

Department of Animal Breeding and Nutrition

Böszörményi 138

H-4032 Debrecen

Hungary

arnyasi@helios.date.hu 